Copyright (C) 2021 University of Bucharest

Printed in Romania. All rights reserved

ISSN print: $1224-5984$

ISSN online: $2248-3942$
Rom Biotechnol Lett. 2021; 26(1): 2207-2213

doi: $10.25083 / \mathrm{rbl} / 26.1 / 2207.2213$

Received for publication, September, 3, 2020

Accepted, October, 18, 2020

Original paper

\title{
Food waste impact on Romanian households
}

\author{
OANA MIHAELA DUMITRU ${ }^{1}$, SORIN CORNELIU IORGA ${ }^{\mathbf{1}}$, \\ ÁNGEL MARTÍNEZ SANMARTIN² \\ ${ }^{1}$ National Institute of Research \& Development for Food Bioresources - IBA Bucharest, \\ 6 Dinu Vintila str., 021102, Bucharest 2, Romania \\ ${ }^{2}$ National Technological Centre for the Food and Canning Industry CTC, Spain
}

\begin{abstract}
Food waste is an increasing issue in the global contexts of food security, scarcity, and the environment. Resources used to generate food raw materials, food processing and distribution have a significant impact on the environment. Our contemporary development pattern, based on consumption stimulation, generates social and geographic disparities, with highly over stimulated consumption in economically developed areas and reduced food availability or even famine in poor communities. As such, we are faced with the both the problems of food waste and food scarcity at the same time.

The present article is assessing the Romanian consumer's food waste impact in 2020, based on data from a nation-wide urban areas statistically representative group.
\end{abstract}

Keywords Food waste, urban consumer, Romania, impact assessment, statistical analysis.

To cite this article: DUMITRU OM, IORGA SC, SANMARTIN ÁM. Food waste impact on Romanian households. Rom Biotechnol Lett. 2021; 26(1): 2207-2213. DOI: $10.25083 / \mathrm{rbl} / 26.1 / 2207.2213$

7 *Corresponding author: SORIN CORNELIU IORGA, National Institute of Research \& Development for Food Bioresources - IBA Bucharest, 6 Dinu Vintila str., 021102, Bucharest 2, Romania E-mail: soriniorga@gmail.com Tel: 0743046536 


\section{Introduction}

The present study is part of the ongoing research on food waste in Romania. Its results are an updated 2020 survey analysing urban households. It aims to measure the impact of food waste behaviour in order to evaluate behavioural transformations since the 2016 impact analysis. In 2016, the level of household food waste in urban areas of Romania was 9,5\% (IORGA, POPA, DUMITRU, 2018).

Food waste remains a topic of high interest for sustainable food development research (STÖCKLI, NIKLAUS \& DORN, 2018). Across the food chain, the final link, households food waste represents a most valuable resource for increasing sustainability, lower the environmental impact and enhance communities responsibility towards food security (SETTI, BANCHELLI, FALASCONI, SEGRÉ \& AL, 2018; YOUNG, RUSSELL, ROBINSON, \& CHINTAKAYALA, 2018). Aktas, Sahin, Topazoglu, Oledina \& al., 2018 studied the food waste generation across the food chain in Qatar. Food waste occurs in every stage of the supply chain, but the value-added lost to waste is the highest when consumers waste food, especially during holiday periods (Ramadan). They emphasised the importance of changing eating and purchasing habits during certain periods of the year. Abdelaradi, 2018 conducted an in-depth analysis of consumers' behaviour in Egypt. Results indicated that healthy and safe food options represent an increasing food choice among respondents, in the context of fresh food purchase to be prepared in households. Perceived food quality and estimated likelihood of consumption at home majorly determine likelihood of choice. Most consumers has been found to prefer "optimal" over 'suboptimal' products when purchasing food (ASCHEMANN-WITZEL, 2018). His online survey among 842 Danish consumers reveals that neither budget savings, organic food or food waste avoidance has an influence on this choice. The individuals' everyday practices regarding food, from shopping to eating, determine the level of food waste. Romani, Grappi, Bagozzi \& Barone, 2018 found that an educational intervention, directed at increasing consumers' perceived skills reduces domestic food waste.

Jaeger, Machin, Aschemann-Witzel \& Antunez, 2018 found also that consumers' perception of food quality, in their case apples, at the point of purchase plays a major role in the purchasing decision. They assessed the influence of some external as well as internal defects and found that external ones lower the rate at which food is purchased by up to $15.1 \%$. Internal defects might lower the rate at which food is purchased by up to $50 \%$.

Consumer perceptions about berry-based products was studied in a comparative analysis in Romania, France and Turkey (POPA, GEICU-CRISTEA, POPA, DRAGHICI $\&$ al, 2017). French consumers appear to be the most loyal consumers of berry-based products out of the three countries investigated, preferring mostly fresh berries, jams and dairy products based on berries. In Turkey and Romania, berry consumption is mostly occasional. Turkish consumers prefer mainly dried berries, while Romanian consumers - the frozen variant and muesli. The study offers valuable information to lower the losses of these highly perishable products. A similar investigation, on motivation and willingness to buy pesticide free food, showed that in Serbia there is great consumers interest in food products produced without the use of pesticides. The main reasons are the desire to maintain personal health and protect the environment (BRANKOV, ŠIBALIJA \& SUBIĆ, 2014).

Grunert, Hieke \& Juhl, 2018 found that both information wants and information use are mainly determined by product involvement and to a lesser extent by health interest.

A cluster analysis on 3834 German and French speaking Swiss consumers identified 6 consumers groups: conservatives, self-indulgent, short-termist, indifferent, consumerist and eco-responsible. The highest ratios are for indifferent and conservative groups, over $51 \%$ of the respondents, which shows the need for coordinated and strong action (DELLEY \& BRUNNER, 2017). Similar analysis on 3,087 Italian respondents, based on selfreporting, revealed these 4 most representative groups: conscious-fussy type, the conscious-forgetful type, the frugal consumer and the exaggerated cook (GAIANI, CALDEIRA, ADORNO, SEGRË \& al, 2018).

A profiling study on high risk wasting food consumers in Romania, found that $1 / 5$ of the population was causing almost $50 \%$ of the total urban households' food waste. The top wasting consumer profile indicates people of age under 35 years, located in big cities, with high income, university degrees, that shop from retail networks (IORGA, APOSTOL, BELC, MOSOIU \& al, 2017). Youth proved to be most inclined to waste food in Spain and Italy as well, as revealed in a survey involving 380 respondents (MONDÉJAR-JIMÉNEZ, FERRARI, SECONDI \& PRINCIPATO, 2016). They concluded that marketing and sales strategies negatively influence the waste behaviour of individuals, emphasizing the important role of retailers in preventing the generation of food waste. Social media is also considered to have a significant influence on the consumers' behaviour (YOUNG, RUSSELL, ROBINSON \& BARKEMEYER, 2017). Theory of Planned Behaviour, Theory of Interpersonal Behaviour and the Comprehensive Model of Environmental Behaviour were used to analyse the consumers' behaviour, in a temporally lagged design with 172 respondents along a period of 14 months. The results pointed to the importance of non-cognitive determinants, like emotions and habits (RUSSEL, YOUNG, UNSWORTH \& ROBINSON, 2017).

The 'green' consumer's profile, based on a survey with 346 respondents revealed that surprisingly, eating organic food does not improve food waste behaviour (MCCARTHY \& LIU, 2017).

A questionnaire survey of 500 Greek households determined that household attitudes towards shopping and eating are important food waste determinants and should not be underestimated. (PONIS, PAPANIKOLAOU, KATIMERTZOGLOU, NTALLA \& al, 2017). Schmidt, 2016, conducted an intervention study on 217 German 
households to promote food waste-prevention. Results indicated improvement of self-reported performances of the recorded food waste-preventing behaviours in the experimental group compared to the control group four weeks following its implementation.

A comparative study on the role of food waste management in two cities from UK, showed the number of frequent recyclers and their levels of satisfaction as higher in the authority which provided a separate food waste collection. In the area which lacked a separate collection service, over three-quarters of respondents would participate in such a scheme if it were available (BEES \& WILLIAMS, 2017).

\section{Materials and Methods}

The study used a survey analysis, based on a multiplechoice questionnaire. The questionnaire followed the content of the previous 2016 study, with updates regarding income levels, in accordance with 2020 income levels. The data was collected in May 2020.

The testing group was selected from among the adult (over 18 years old) urban population, a randomised stratified sample of 991 respondents, for which we generated 21.589 calls, by random digit dialling method.
The respondents were interviewed through the Computer Assisted Telephone Interview (CATI) method, with an average call duration of 12.3 minutes.

The margin error is $+/-3.1 \%$.

Data analysis and interpretation was made with the SPSS Statistic Data Editor Program. Results were presented by descriptive statistics, and One-Way ANOVA and Bivariate methods were applied to identify and discuss correlations.

\section{Results}

\section{Target group structure}

The age percentiles indicate $25 \%$ of the group under 25 y.o., $50 \%$ under 48 y.o and $75 \%$ under 63 y.o. Gender distribution is male/female: $47.7 \% / 52.3 \%$.

Main education level is high school (35\%), and $75 \%$ have no higher than college education (Table 1).

The main value of household community is 3.4742 , with 0,9482 children under 16 y.o.

Over half of the respondents have a monthly family income up to 3.500 lei (53.6\%). 67 indicated their incomes over 10.000 lei, and 23 declared under 750 lei/month/ family (Table 2).

Table 1. Target group descriptive data

\begin{tabular}{|cccccc|}
\hline \multicolumn{2}{|c}{ Gender } & \multicolumn{2}{c|}{ Age } & \multicolumn{2}{c|}{ Education } \\
\hline Female & $52.3 \%$ & $18-35$ y.o. & $26.5 \%$ & General education & $32.8 \%$ \\
\hline Male & $47.7 \%$ & $36-65$ y.o. & $54.5 \%$ & Highschool & $35 \%$ \\
\hline & $66-90$ y.o. & $19 \%$ & Higher education & $32.1 \%$ \\
\hline & Mean, y.o. & 48,8139 & & \\
\hline
\end{tabular}

Table 2. Family monthly income in Romanian urban households in 2020

\begin{tabular}{|cc|}
\hline No income & $1.8 \%$ \\
$<750$ lei & $2.5 \%$ \\
$750-1.500$ lei & $10.7 \%$ \\
$1.501-2.500$ lei & $19 \%$ \\
$2.501-3.500$ lei & $19.6 \%$ \\
$3.501-4.500$ lei & $14.3 \%$ \\
$4.501-5.500$ lei & $8.4 \%$ \\
$5.501-6.500$ lei & $7 \%$ \\
$6.501-10.000$ lei & $9.5 \%$ \\
$>10.000$ lei & $7.1 \%$ \\
\hline
\end{tabular}

\section{Food waste findings}

$67.2 \%$ of the respondents consider they are wasting up to $5 \%$ of their food. $17.6 \%$ admitted to waste between $11-20 \%$ and 57 respondents consider they are wasting over $20 \%$ of their purchased food. The mean value of the weekly quantity of food wasted is $0.4557 \mathrm{~kg} /$ household (Table 3).
The average food purchasing budget is between 1.001-2.000 lei/month/household (936 respondents). 419 respondents admitted their budget increased in the last 12 months; other 430 considered that their budget remained more or less the same. Only 127 respondents reported a decrease in their food purchasing budgets and 15 could not or did not want to answer (Table 4).

Table 3. Food waste impact on Romanian urban households in 2020

\begin{tabular}{|cccc|}
\hline Food waste, \% & Percentage & Food waste, kg & Percentage \\
\hline 0 & $20.2 \%$ & 0.1 & $45.7 \%$ \\
\hline $0.5-2.5$ & $24.5 \%$ & 0.25 & $23 \%$ \\
\hline $3-5$ & $22.5 \%$ & 0.75 & $21.6 \%$ \\
\hline $6-10$ & $17.6 \%$ & 1.5 & $6.7 \%$ \\
\hline $11-20$ & $9.4 \%$ & 2.5 & $1.8 \%$ \\
\hline$>20$ & $5.8 \%$ & 3.5 & $0.6 \%$ \\
\hline & & 4 & $0.6 \%$ \\
\hline
\end{tabular}


Table 4. Monthly food purchasing budget data

\begin{tabular}{|cccc|}
\hline Budget in 2020 & \multicolumn{2}{c|}{ Budget evolution 2019/2020 } \\
\hline$<500$ lei & $30.7 \%$ & Increased & $42.9 \%$ \\
\hline $501-1.000$ lei & $37.8 \%$ & Approximately the same & $44.1 \%$ \\
\hline $1.001-2.000$ lei & $26.2 \%$ & Lowered & $13 \%$ \\
\hline$>2.001$ lei & $5.3 \%$ & & \\
\hline
\end{tabular}

\section{Food waste behavioural determinants}

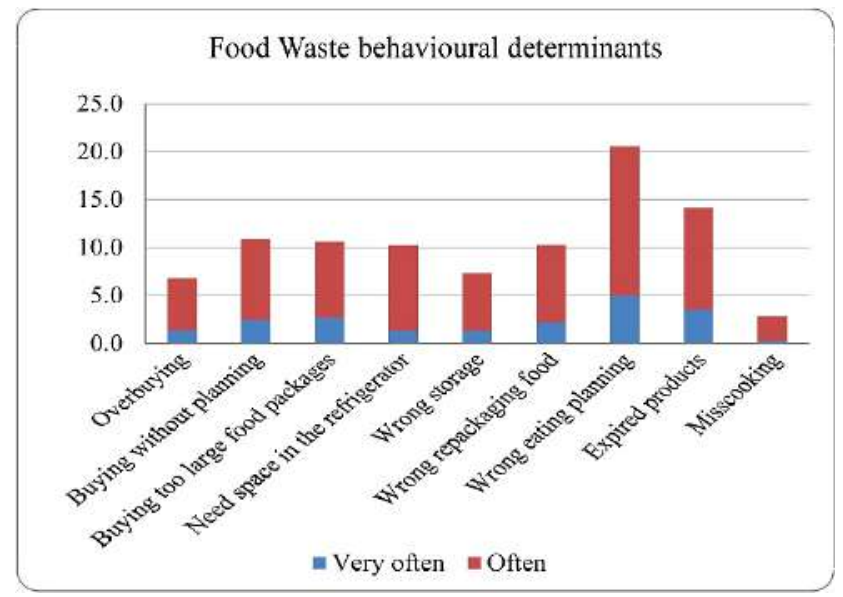

Figure 1. Food waste behavioural determinants

\section{Purchasing habits (locations)}

Most of the respondents indicated retail networks as their main shopping destination $(70 \%)$, which suggests

\section{Food categories}

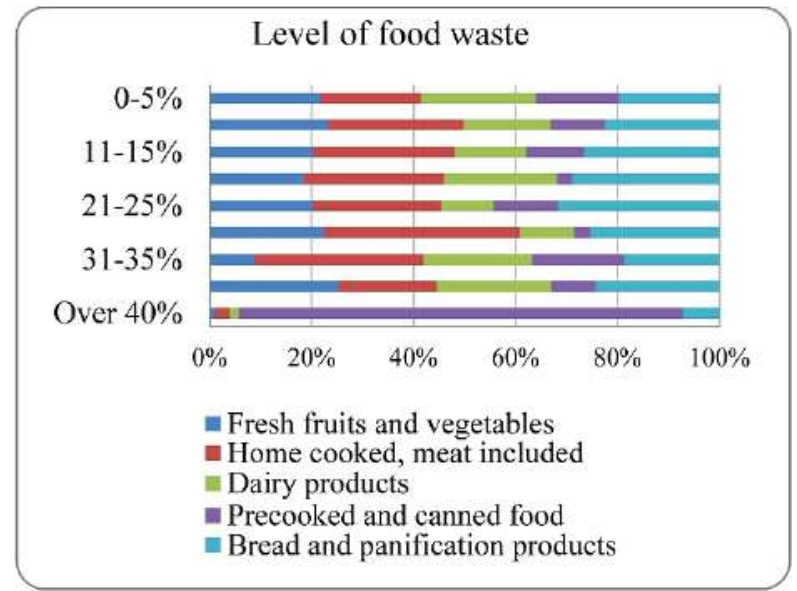

Figure 2. Food waste assessment for some food categories

the role of corporate distribution in food waste management in urban area.

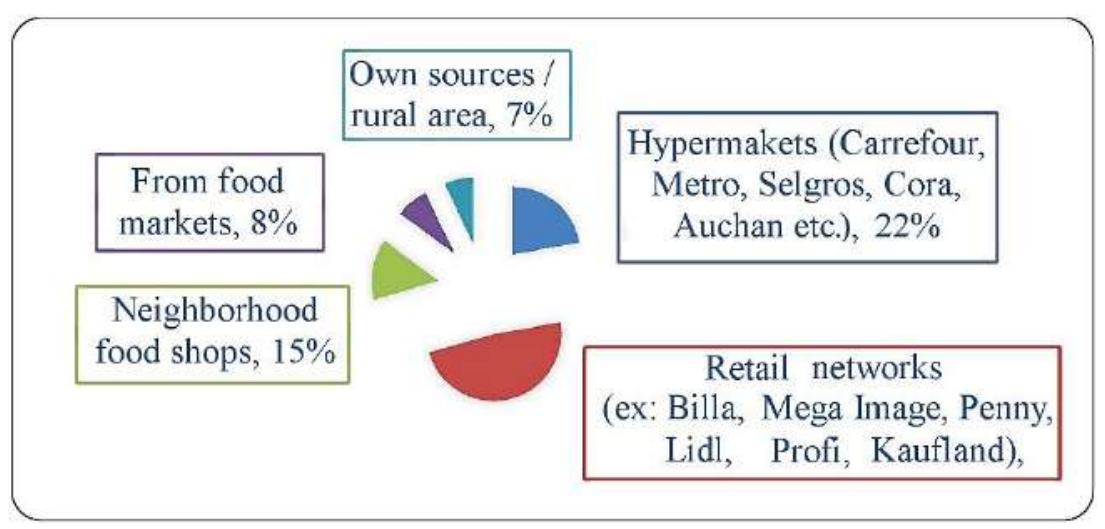

Figure 3. Main food shopping locations choices

\section{Discussion}

Anova One Way method indicate strong correlations of households' food waste level $(\sigma<0.05)$ upon some factors: gender, age, education, income, and geographical criteria (region). The level is also influenced by the households' size (number of members, number of children under 16 years old). The computed data of food waste level per capita (FW per capita) seems to be similarly correlated, less the presence of underage children in the family, which does not seems to determine a different food waste behaviour.

\section{Individual determinants of food waste}

Female respondents seem to have a more responsible food waste behaviour than male respondents (Figure 4). 


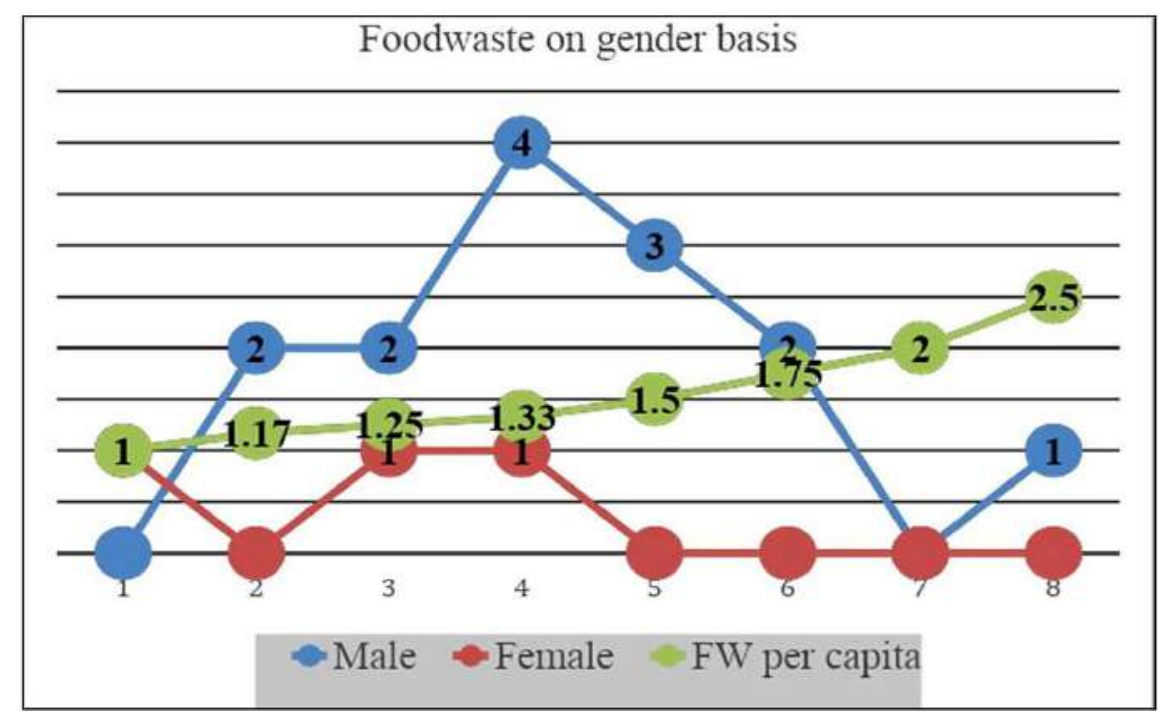

Figure 4. Food waste / Gender correlations

Age correlations indicates the group of respondents over 65 years old are more likely to pay attention to food consumption. Young adults ( $<35$ years old) and middle age respondents are more likely to waste food (Figure 5).

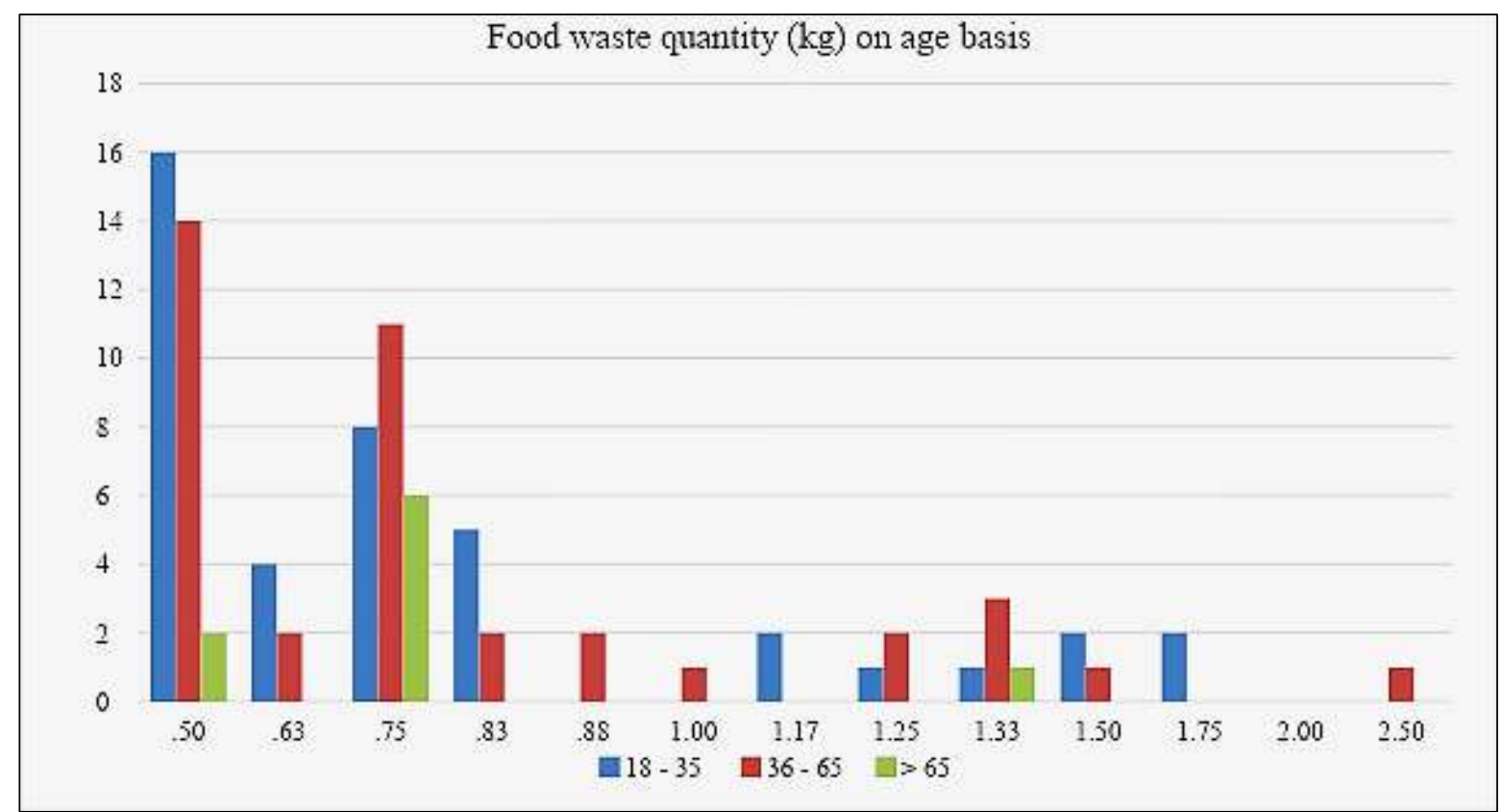

Figure 5. Households food waste quantity $(\mathrm{kg})$ / Age correlation (am specificat tipul de risipa, anume cantitativa)

\section{Household determinants of food waste}

Analysis of family income influence on households food waste level $(\%)$, indicates that monthly incomes over 3.500 lei are most likely to induce high level of food waste (over 11\%), however the higher income levels do not necessarily determine a higher food wasting behaviour (Figure 6). 


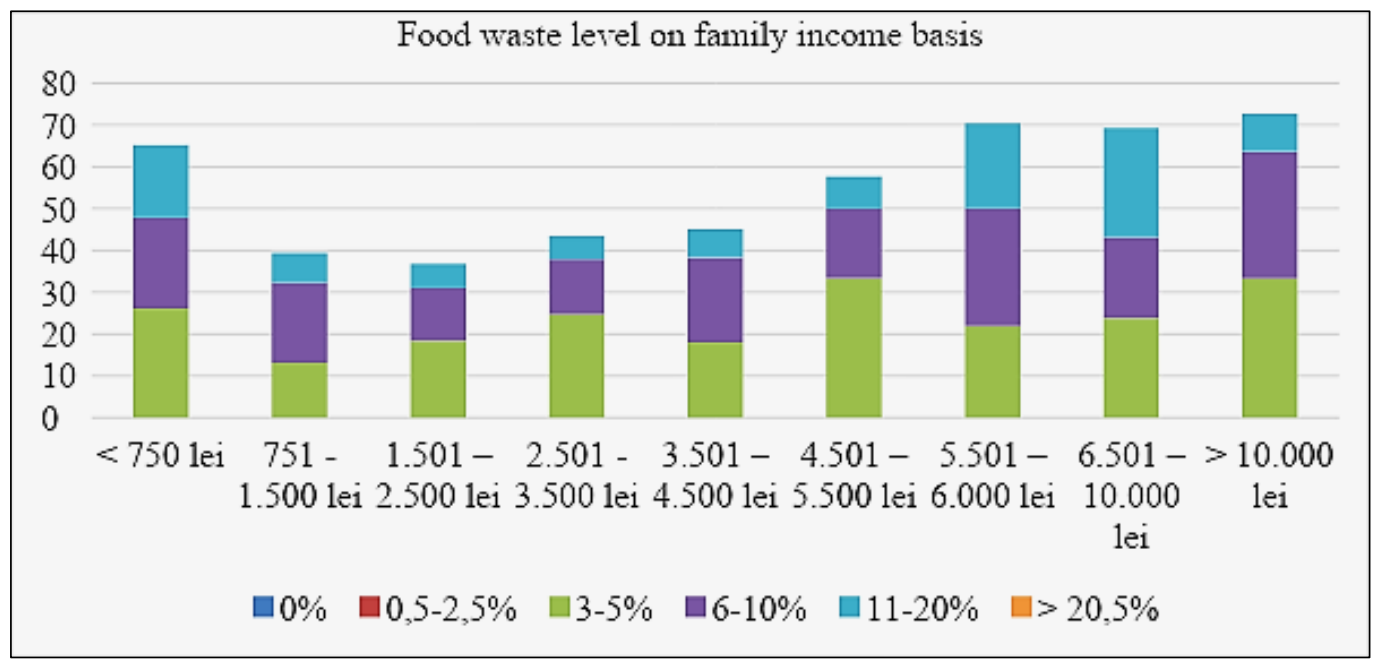

Figure 6. Households food waste level (\%) / Family income correlation

Household size correlates to food wasting behaviour. Higher peaks are for 3 to 7 member households, which indicates conflicts on food choices or food remains management. Data indicate that larger households are more responsible in managing their food resources, their level of food waste being under the mean value of $4.557 \%$ (Figure 7).

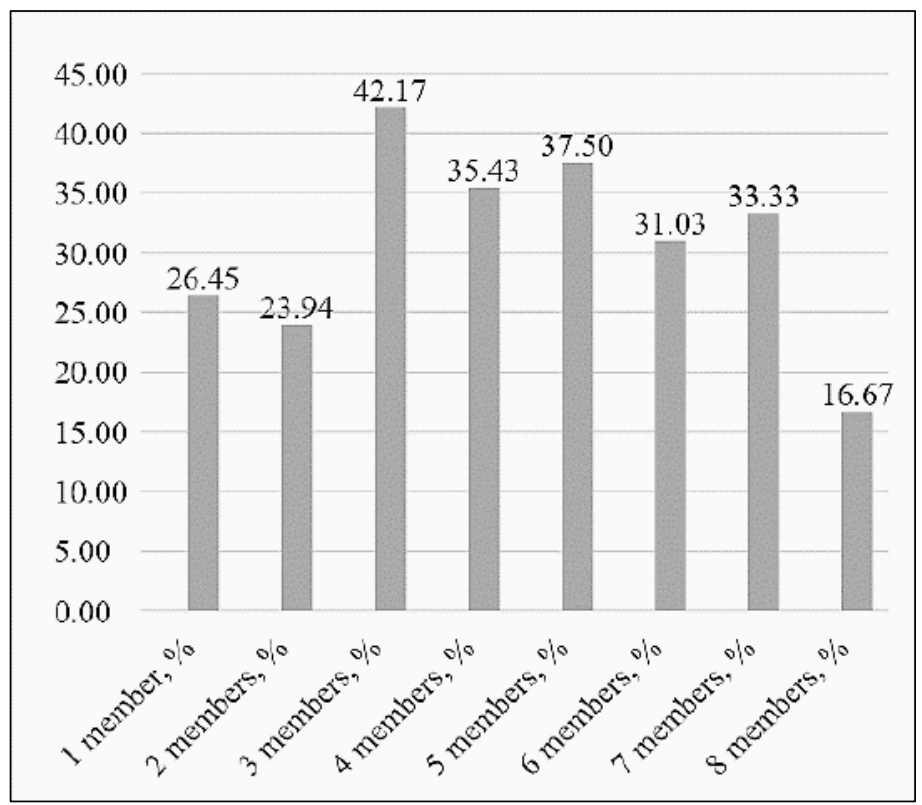

Figure 7. The percentage of high food wasting households, by their size

\section{Conclusions}

The present study is a follow-up survey of Romanian consumer behaviour in food waste generation. It is meant to support national efforts in reducing the food waste impact on the food chain, from farm to fork. Compared to previous 2016 survey, the food waste level mean value, of $10.5 \%$ (IORGA, APOSTOL, BELC, MOSOIU \& al, 2017) is significantly higher than the 2020 level (6.5\%). The respondents reported a certain reducing tendency in food waste $(43.5 \%)$, but the general trend is rather constant $(52.4 \%)$. At the same time, the monthly food consumer price index for April 2020/ August 2016 is 118.23 (http://statistici.insse.ro/shop/?page=ipc1\&lang=ro) and the monthly income index April 2020/August 2016 is 153.3 (https://insse.ro/cms/ro/content/c\%C3\%A2\%C8\%99tigurisalariale-din-1991-serie-lunar\%C4\%83), which suggests an increase in the purchasing power of the population during this period. The reduced level of food waste could be the result of increased consumer responsibility, due to 
public awareness campaigns, public policies implemented. It could also indicate that COVID 19 has influenced 2020 consumer perception data, within the context of general lower consumption in Romanian society. This indicates the need to confirm the survey data in a COVID 19 free or medically controlled context.

\section{Acknowledgements}

The present article uses research data supported by the ADER Program of the Ministry of Agriculture and Rural Development, project 18.1.2. - Methods for reducing food waste in the agri-food chain, at national level, in order to prevent and reduce the socio-economic impact, by 2030.

\section{References}

1. F. ABDELRADI. Food waste behaviour at the household level: A conceptual framework, Waste Management 71, 485-493 (2018).

2. E. AKTAS, H. SAHIN, Z. TOPALOGLU, A. OLEDINMA, A.K.S. HUDA, Z. IRANI, A.M. SHARIF, T.V. WOUT, M. KAMRAVA. A consumer behavioural approach to food waste, Journal of Enterprise Information Management, 31(5), 658-673 (2018).

3. J. ASCHEMANN-WITZEL. Consumer perception and preference for suboptimal food under the emerging practice of expiration date based pricing in supermarkets, Food Quality and Preference 63, 119-128 (2018).

4. A.D. BEES, I.D. WILLIAMS. Explaining the differences in households food waste collection and treatment provisions between local authorities in England and Wales, Waste Management 70, 222-235 (2017).

5. S.V. RUSSELL, C.W. YOUNG, K.L. UNSWORTH, C. ROBINSON. Bringing habits and emotions into food waste behaviour, Resources, Conservation \& Recycling 125, 107-114, (2017).

6. T.P. BRANKOV, T. ŠIBALIJA, J. SUBIĆ. Serbian consumers' willingness to buy food products produced without the use of pesticides, Romanian Biological Letters 19(4), 9605-9614 (2014).

7. M. DELLEY, T.A. BRUNNER. Foodwaste within Swiss households: A segmentatio of the population and suggestions for preventive measures, Resources, Conservatio and Recycling 122, 172-184 (2017).

8. S. GAIANI, S. CALDEIRA, V. ADORNO, A. SEGRÈ, M. VITTUARI. Food wasters: Profiling consumers' attitude to waste food in Italy, Waste Management 72, 17-24 (2018).

9. K.G. GRUNERT, S. HIEKE, H.J. JUHL. Consumer wants and use of ingredient and nutrition information for alcoholic drinks: A cross-cultural study in six EU countries, Food Qualitiy and Preference, 63, 107-118 (2018).

10. S.C. IORGA, L. APOSTOL, N. BELC, C.E. MOSOIU, L.M. BERCA, O.M. NICULAE, M.E. POPA. Profile of high risl wasting food consumer in Romania, Scientific Bulletin. Series F. Biotechnologies, 21, 301-307 (2017).
11. S. IORGA, M.E. POPA, O.M. DUMITRU. Causes and dimensions of food waste in the households of Romania, International Book Market Service Ltd., 17 Meldrum Street, Beau Bassin 71504, Mauritius, ISBN: 978-620-2-31162-5 (2018).

12. S.R. JAEGER, L. MACHIN, J. ASCHEMANNWITZEL, L. ANTUNEZ. Buy, eat or discard? A case study with apples to explore fruit quality perception and food waste, Food Quality and Preferance 69, 10-20 (2018).

13. B. MCCARTHY, H.B. LIU. Food waste and the 'green' consumer, Australian Marketing Journal 25, 126-132 (2017).

14. J.-A. MONDÉJAR-JIMÉNEZ, G. FERRARI, L. SECONDI, L. PRINCIPATO. From the table to waste: An exploratory study on behaviour towards food waste of Spanish and Italian youths, Journal of Cleaner Production 138(1), 8-18 (2016).

15. S.T. PONIS, P.-A. PAPANIKOLAOU, P. KATIMERTZOGLOU, A.C. NTALLA, K.I. XENOS. Household food waste in Greece: A questionnaire survey, Journal of Cleaner Production 149, 12681277 (2017).

16. M.E. POPA, M. GEICU-CRISTEA, A. POPA, M. DRAGHICI, E.E. TANASE, A. MITELUT, C.S. IORGA, C. GUILLAUME, N. GONTARD, V. GUILLARD, F. GOGU, D.K. YANIK. Consumption and attitudes regarding berries-based products - comparative analysis of Romania, France and Turkey, Romanian Biotechnological Letters, 22(3), 12568-12576 (2017).

17. S. ROMANI, S. GRAPPI, R.P. BAGOZZI, A.M. BARONE. Domestic food practices: A study of food management behaviours and the role of food preparation planning in reducing waste, Appetite 121, 215-227 (2018).

18. K. SCHMIDT. Explaining and promoting household food waste-prevention by an environmental psychological based intervention study, Resources, Conservation and Recycling 111, 53-66 (2016).

19. M. SETTI, F. BANCHELLI, L. FALASCONI, A. SEGRÉ, M. VITTUARI. Consumers' food cycle and household waste. When behaviors matter, Journal of Cleaner Production 185, 694-706 (2018).

20. S. STÖCKLI, E. NIKLAUS, M. DORN. Call for testing interventions to prevent consumer food waste, Resources, Conservation \& Recycling 136, 445-462 (2018).

21. C.W. YOUNG, S.V. RUSSELL, C.A. ROBINSON, P.K. CHINTAKAYALA. Sustainable Retailing - Influencing Consumer Behaviour on Food Waste, Business Strategy and the Environment 27, 1-15 (2018).

22. C.W. YOUNG, S.V. RUSSELL, C.A. ROBINSON, R. BARKEMEYER. Can social media be a tool for reducing consumers' food waste? A behaviour change experiment by a UK retailer, Resources, Conservation \& Recycling 117, 195-203 (2017).

23. http://statistici.insse.ro/shop/?page=ipc1\&lang=ro

24. https://insse.ro/cms/ro/content/c\%C3\% A2\%C8\% 99tiguri-salariale-din-1991-serie-lunar\%C4\%83 